\title{
Efficacy appraisal of fungicides against Fuasarium oxysporium f. lini in linseed for better management strategy
}

\author{
ANJANA ARUN ${ }^{1}$ AND C.S. CHOUDHARY* \\ Regional Research Station, Agwanpur, SAHARSA (BIHAR) INDIA \\ ${ }^{1}$ Department of Plant Pathology, Rajendra Agricultural University, Pusa, SAMASTIPUR (BIHAR) INDIA
}

\section{ARITCLE INFO}

Received : 27.08 .2014

Revised : 10.03 .2015

Accepted : 24.03.2015

KEY WORDS :

Linseed, Fuasarium oxysporium f. lini, Management, Fungicides

*Corresponding author:

Email: csrau07@gmail.com

\begin{abstract}
Out of the seven fungicides tested in vitro against Fusarium oxysporum f. lini, carbendazim 50WP and benlate 50WP were found most effective in checking the colony growth to $00 \mathrm{~mm}$ (completely check) followed by thiram75WP $(10.52 \mathrm{~mm})$, captafol 80WP $(14.21 \mathrm{~mm})$ and captan 50WP (15.24 mm). In field trial studies, seedling emergence and mortality inhibition were maximum in case of the seeds treated with Trichoderma viride $(92.35 \%$ and $5.63 \%)$ followed by carbendazim 50WP (84.60\% and 6.96\%). Maximum linseed yield (7.93q/ha) was obtained when seeds treated with Trichoderma viride $\left(10^{7}\right.$ spores/g).
\end{abstract}

How to view point the article : Arun, Anjana and Choudhary, C.S. (2015). Efficacy appraisal of fungicides against Fuasarium oxysporium $\mathrm{f}$. lini in linseed for better management strategy. Internat. J. Plant Protec., 8(1) : 181-183. 